\title{
Serovar specific immunity to Neisseria gonorrhoeae: does it exist?
}

\author{
J D C Ross, A Moyes, H Young
}

\begin{abstract}
Objective-To determine whether the host immune response to gonorrhoea provides limited serovar specific protection from reinfection.

Subjects-508 episodes of gonorrhoea diagnosed at a city centre genitourinary medicine clinic including 22 patients with multiple infections over a 4 year period. Methods-Patients with recurrent gonococcal infection were analysed with respect to the initial and subsequent serovars isolated.

Results-No significant difference was seen in the prevalence of serovars isolated following a repeat infection compared with those without repeat infections. The site of the initial infection did not appear to influence the subsequent serovar isolated.

Conclusion-We found no evidence of serovar specific immunity in our population. It remains possible that populations with a higher prevalence of gonorrhoea and more frequent infections may have a quantitatively greater immune response.
\end{abstract}

(Genitourin Med 1995;71:367-369)

Keywords: gonorrhoea, immunity, serotyping, sexua orientation

\section{Introduction}

The host immune response to gonococcal infection is primarily humoral in nature and, although a variety of antibodies can be detected both in serum ${ }^{1-3}$ and in genital secretions, ${ }^{4-7}$ individuals with gonorrhoea do not appear to be protected from reinfection with $N$ gonorrhoeae as occurs with many other bacterial infections. This lack of protective immunity gives rise to the "core group" theory of infection, where a small core group of individuals with multiple partners produce the majority of infections within a community. However, it has been suggested that limited serovar specific immunity may occur and reinfection of an individual with the same serovar of $N$ gonorrhoeae may be less likely than with a different strain. ${ }^{9}$ In this context it is of interest that immunoglobulin in vaginal fluid reacts comparatively more with Protein I, the serotyping antigen, than does immunoglobulin in serum ${ }^{7}$.

This study was designed to examine recurrent gonococcal infections in patients attending a Department of Genitourinary Medicine with respect to their initial and subsequent serovar as a surrogate marker of serovar specific immunity.

\section{Methods}

All patients presenting to the Department of Genitourinary Medicine at Edinburgh Royal Infirmary between January 1990 and December 1993 were analysed. The diagnosis of gonorrhoea was made on the basis of culture of $N$ gonorrhoeae on modified New York culture medium from the urethra, rectum, endocervix and/or throat. All male patients had a single urethral swab taken whilst female patients had urethral and endocervical swabs cultured on two separate occasions to diagnose or exclude gonorrhoea. Throat cultures were performed in all partners of patients with gonorrhoea and when the history indicated that this site had been placed at risk. Rectal cultures were taken routinely from men who gave a history of homosexual contact and from all women.

Gonococcal isolates were identified on the basis of biochemical and immunological tests and serotyping was performed using the American panel of monoclonal antibodies as has been described previously. ${ }^{10}$

Information was obtained from the casenotes of patients with a diagnosis of gonorrhoea on age, sex, sexual orientation and date of diagnosis. The data on serovar prevalence was then analysed with respect to the clinical information.

The data were entered into the dBase (Borland Software) database program and statistical analysis was performed using chi square on the Epiinfo statistical package (WHO public domain software)

\section{Results}

Five hundred and eight patient episodes of gonoccoal infection occurred over the 4 year study period. Twenty one patients were infected with gonorrhoea on two separate occasions over the four year study period and one patient on three occasions (total of 45 infectious episodes). The sex, age, sexual orientation, time between infections, serovars isolated and serovars of sexual contacts are shown in the table. Eighteen of the patients were homosexual and four heterosexual (one male and three female). Six homosexual patients were initially infected with serovar 1B-2 and three of these were subsequently reinfected with the same serovar $(50 \%)$. The 
Table Re-infection with gonorrhoea in Edinburgh

\begin{tabular}{|c|c|c|c|c|c|}
\hline Sex & $\begin{array}{l}\text { Age } \\
\text { (years) }\end{array}$ & $\begin{array}{l}\text { Sexual } \\
\text { orientation }\end{array}$ & $\begin{array}{l}\text { Time interval } \\
\text { between infections } \\
\text { (months) }\end{array}$ & $\begin{array}{l}\text { Serovar } \\
\text { (first/second/third }\end{array}$ & $\begin{array}{l}\text { Serovar of } \\
\text { initial partner }\end{array}$ \\
\hline $\begin{array}{l}F \\
F \\
F \\
M \\
M \\
M \\
M \\
M \\
M \\
M \\
M \\
M \\
M \\
M \\
M \\
M \\
M \\
M \\
M \\
M \\
M \\
M\end{array}$ & $\begin{array}{l}17 \\
20 \\
18 \\
24 \\
39 \\
32 \\
23 \\
32 \\
34 \\
38 \\
29 \\
23 \\
41 \\
22 \\
24 \\
19 \\
24 \\
24 \\
22 \\
28 \\
24 \\
26\end{array}$ & $\begin{array}{l}\text { heterosexual } \\
\text { heterosexual } \\
\text { heterosexual } \\
\text { heterosexual } \\
\text { homosexual } \\
\text { homosexual } \\
\text { homosexual } \\
\text { homosexual } \\
\text { homosexual } \\
\text { homosexual } \\
\text { homosexual } \\
\text { homosexual } \\
\text { homosexual } \\
\text { homosexual } \\
\text { homosexual } \\
\text { homosexual } \\
\text { homosexual } \\
\text { homosexual } \\
\text { homosexual } \\
\text { homosexual } \\
\text { homosexual } \\
\text { homosexual }\end{array}$ & $\begin{array}{r}28 \\
8 \\
5 \\
14 \\
17 \\
6 \\
31 \\
10 \\
29 \\
14 \\
9 \\
13 / 16 \\
19 \\
15 \\
17 \\
35 \\
28 \\
4 \\
4 \\
1 \\
9 \\
7\end{array}$ & $\begin{array}{l}1 \mathrm{~A}-6 / 1 \mathrm{~A}-2 \\
1 \mathrm{~B}-2 / 1 \mathrm{~B}-2 \\
1 \mathrm{~B}-2 / 1 \mathrm{~B}-2 \\
1 \mathrm{~B}-6 / 1 \mathrm{~B}-2 \\
1 \mathrm{~B}-6 / 1 \mathrm{~B}-1 \\
1 \mathrm{~B}-6 / 1 \mathrm{~B}-6 \\
1 \mathrm{~B}-6 / 1 \mathrm{~B}-2 \\
1 \mathrm{~B}-2 / 1 \mathrm{~B}-5 \\
1 \mathrm{~B}-3 / 1 \mathrm{~B}-2 \\
1 \mathrm{~B}-3 / 1 \mathrm{~B}-2 \\
1 \mathrm{~B}-2 / 1 \mathrm{~B}-15 \\
1 \mathrm{~B}-2 / 1 \mathrm{~B}-7 / 1 \mathrm{~B}-2 \\
1 \mathrm{~B}-6 / 1 \mathrm{~B}-2 \\
1 \mathrm{~B}-6 / 1 \mathrm{~B}-2 \\
1 \mathrm{~B}-2 / 1 \mathrm{~B}-2 \\
1 \mathrm{~B}-6 / 1 \mathrm{~A}-6 \\
1 \mathrm{~B}-2 / 1 \mathrm{~B}-6 \\
1 \mathrm{~B}-3 / 1 \mathrm{~B}-2 \\
1 \mathrm{~B}-3 / 1 \mathrm{~B}-6 \\
1 \mathrm{~B}-2 / 1 \mathrm{~B}-2 \\
1 \mathrm{~B}-6 / 1 \mathrm{~B}-2 \\
1 \mathrm{~B}-7 / 1 \mathrm{~A}-6\end{array}$ & $\begin{array}{l}1 \mathrm{~A}-6 \\
1 \mathrm{~B}-2\end{array}$ \\
\hline
\end{tabular}

Reinfection with same virus marked in bold. the same strain subsequently. ${ }^{9}$ Our data do not support the presence of such immunity with no difference observed in the reinfection rates for patients previously infected. Unlike the African study the reinfections that we observed occurred primarily in homosexual men who may differ from women in the magnitude of their immune response to infection. The serum antibody response is greater in women than men, possibly reflecting a greater infective burden in the female genital tract or a more chronic infectious process. ${ }^{1920}$ Infection at multiple sites might also be expected to invoke a greater immune response. The site of initial infection did not appear to influence the serovar subsequently isolated although the numbers involved are small and a significant difference cannot be ruled out.

There are other important differences between the two studies. The time period for the African study was 16 months during which period the women had an average of four gonococcal infections. Our study took place over four years during which period patients had on average only 1.04 infections although this was higher in gay men (1.11 infections). Nevertheless the time interval betwen infections in our study averaged 14.7 months (range 1-35) allowing more time for an antibody response, particularly a local mucosal response, to wane. Therefore the conclusion from the African study ${ }^{9}$ that infection with a specific gonococcal serovar results in specific but incomplete protection against subsequent infection with the homologous serovar only holds for a highly active population with frequent exposure after a short time interval.

It is also possible that some of those re-presenting with isolates of the same serotype had been inadequately treated or non compliant with therapy rather than reinfected. This may account for some episodes which re-presented after a short time interval but is unlikely to be a major factor for those with a longer interval between infections. Although one case of presumed re-infection in the study occurred after one month the remainder had a time interval of at least four months making it unlikely that this would compromise the study's conclusions.

The results of our study do not support the concept of serovar specific immunity to gonococcal infections occurring in homosexual men. Because of the low level of gonorrhoea in this population and the limited number of infections immunity does not appear to be a major variable in determining the prevalence of infection.

1 Kearns DH, Seibert GB, O'Reilly R, Lee L, Logan L Paradox of the immune response to uncomplicated gonococcal urethritis. N Engl f Med 1973;289:1170-4.

2 Brooks GF. Pathogenesis and immunology of gonococcal infection. In: Brooks GF, Donegan EA, eds. Gonococcal Infection. London: Edward Arnold, 1985:58-82.

3 Zak K, Diaz JL, Jackson D, Heckels JE. Antigenic variation during infection with Neisseria gonorrhoeae: detection of antibodies to surface proteins in sera of patients with gonorrhea. F Infect Dis 1984;149:166-74.

4 McChesney D, Tramont EC, Boslego JW, Ciak J, Sadoff J, Brinton CC. Genital antibody response to a parenteral gonococcal pilus vaccine. Infect Immun 1982;36: gonococcal

5 Tramont EC. Inhibition of adherence of Neisseria gonorrhoeae by human genital secretions. $\mathcal{f}$ Clin Invest 1977; 59:117-24.
A study of prostitutes in Africa found that women infected with one Protein I gonococcal strain are less likely to become reinfected with 
6 Tramont EC, Ciak J, Boslego J, McChesney DG, Brinton $\mathrm{CC}$, Zollinger W. Antigenic specificity of antibodies in vaginal secretions during infection with Neisseria gonorhoeae. F Infect Dis 1980;142:23-31.

7 Lammel CJ, Sweet RL, Rice PA, et al. Antibody-antigen specificity in the immune response to infection with Neisseria gonorrhoeae. I Infect Dis 1985;152. 990-1001.

8 Yorke JA, Hethcote HW, Nold A. Dynamics and control of the transmission of gonorrhea. Sex Transm Dis 1978; 5:51-6.

9 Plummer FA, Simonsen JN, Chubb H, et al. Epidemiologic evidence for the development of serovar-specific immunity after gonococcal infection. J Clin Invest 1989 83:1472-6.

10 Moyes A, Young H. epidemiological typing of Neisseria gonorrhoeae: a comparative analysis of three monoclonal antibody serotyping panels. Eur $\mathcal{f}$ Epidemiol 1991;7: 311-9.

11 Hicks CB, Boslego JW, Brandt B. Evidence of serum antibodies to Neisseria gonorrhoeae before gonococcal infection. F Infect Dis 1987;155:1276-81

12 Sarafian SK, Tam MR, Morse SA. Gonococcal protein Ispecific opsonic IgG in normal human serum. F Infect Dis 1983;148:1025-32.

13 Fohn MJ, Mietzner TA, Hubbard TW, Morse SA, Hook EW. Human immunoglobulin $G$ antibody response to the major gonococcal iron-regulated protein. Infect Immun 1987;55:3065-9.

14 Hook EW, Olsen DA, Buchanan TM. Analysis of the antigen specificity of the human serum immunoglobulin $G$ immune response to complicated gonococcal infection. Infect Immun 1984;43:706-9.

15 Rice PA, Vayo HE, Tam MR, Blake MS. Immunoglobulin $G$ antibodies directed against protein III block killing of serum-resistant Neisseria Serum-resistant Neisseria gonor

16 James JF, Zurlinden E, Lammel CJ, Brooks GF. Relation of protein I and colony opacity to serum killing of of protein I and colony opacity to serum killin.

17 Heckels JE, Virji M, Zak K, Fletcher JN. Immunobiology of gonococcal outer membrane protein I. Antonie Van Leeuwenhoek 1987;53:461-4

18 Joiner KA, Warren KA, Tam M, Frank MM. Monoclona antibodies directed against gonococcal protein vary in bactericidal activity. F Immunol 1985;134: 3411-9.

19 Buchanan TM, Swanson J, Holmes KK, Kraus SJ, Gotschlich EC. Quantitative determination of antibody to gonococcal pili. Changes in antibody levels with gonococcal infection. $\mathcal{F}$ Clin Invest 1973;52:2896-909.

20 Welch BG, O'Reilly RJ. An indirect fluorescent-antibody technique for study of uncomplicated gonorrhea. I. technique for study of uncomplicated
Methodology. $\mathcal{F}$ Infect Dis 1973;127:69-76 